\title{
Seed-transmission of Cowpea mild mottle virus on several varieties of soybean in Indonesia
}

\author{
MIMI SUTRAWATI ${ }^{1, \bullet}$, SRI HENDRASTUTI HIDAYAT ${ }^{2}$, GEDE SUASTIKA ${ }^{2}$, \\ BONNY PURNOMO WAHYU SUKARNO ${ }^{2}$, ALI NURMANSYAH ${ }^{2}$ \\ ${ }^{1}$ Program of Plant Protection, Faculty of Agriculture, Universitas Bengkulu. Jl. WR. Supratman, Kandang Limun, Bengkulu City 38371, Bengkulu, \\ Indonesia. Tel./fax.: +62-732-342584, `email: mimi_sutrawati@unib.ac.id \\ ${ }^{2}$ Department of Plant Protection, Faculty of Agriculture, Institut Pertanian Bogor. Jl. Kamfer, Kampus IPB Dramaga, Bogor 16680, West Java, Indonesia
}

Manuscript received: 19 September 2019. Revision accepted: 14 September 2021.

\begin{abstract}
Sutrawati M, Hidayat SH, Suastika G, Sukarno BPW, Nurmansyah A. 2021. Seed-transmission of Cowpea mild mottle virus on several varieties of soybean in Indonesia. Biodiversitas 22: 4182-4185. Seeds and infected plants play important role as source of disease in the field for seed-transmitted virus, such as Cowpea mild mottle virus (CPMMV). Research was conducted to determine seed transmission nature of CPMMV on 10 soybean varieties based on growing on test method and dot immunobinding assay to confirm CPMMV infection. Field experiment was conducted to evaluate the efficiency of seed-transmitted CPMMV as the source of initial inoculum in the field. Soybean var. 'Anjasmoro' from 3 cultivation areas (Cianjur, Bogor, and Cirebon) was used for field experiment. Seed transmission of CPMMV was confirmed on soybean var. 'Detam 2', 'Detam 3', 'Malika', 'Anjasmoro', and 'Argomulyo'; but was not found on 'Detam 1', 'Detam 4', 'Wilis', 'Grobogan', and 'Dena 1'. The infection of CPMMV did not show symptom, either on the seedcoat and the unifoliolate leaves. Infection rate of CPMMV on seeds were relatively high, ranged between 27 to $86 \%$. Disease incidence on var. 'Anjasmoro' from Cianjur, Cirebon, and Bogor varied from 32.9 to $75 \%$ and 57.9 to $81.3 \%$ in screenhouse and field experiment, respectivelly.
\end{abstract}

Keywords: Dot immunobinding assays, growing on test, infected seed, inoculum resource, seedcoat

Abbreviations: CPMMV: Cowpea mild mottle virus, DIBA; dot immunobinding assay, WAP: week after planting. DAP: Day after planting

\section{INTRODUCTION}

Virus infection on soybeans have the potential to cause yield loss and reduce the quality of seeds. Soybean mosaic virus (SMV) (Andayanie 2012), Cucumber mosaic virus strain soybean (CMV-S) and Pepper yellow leaf curl virus (PYLCV) (Rahim et al. 2015) were reported recently infecting soybean plants in Java. Cowpea mild mottle virus (CPMMV) was first reported to cause systemic mottling, chlorotic blotches and leaf malformations in cowpea (Vigna unguiculata L.) in 1973 and to be widespread in the Eastern Region of Ghana, West Africa. Since then, it has been described to naturally infect other leguminous crops such as peanut (Arachis hypogaea L.), soybean (Glycine $\max$ L.) and common bean (Phaseolus vulgaris L.). The first report of CPMMV infecting yardlong bean was in 2012 in Venezuela (Brito et al. 2012). This virus has been reported to infect cowpea and French bean in Taiwan (Chang et al. 2013). Carlaviruses can reduce yields of some crop species by $10 \%-15 \%$ and, in mixed infections, can exacerbate the deleterious effects of other viruses (Tavasoli et al. 2009). CPMMV is transmitted in a non-persistent manner by the whitefly Bemisia tabaci G. (Hemiptera: Aleyrodidae) and has also been assigned to the genus Carlavirus, currently classified in the family Betaflexiviridae (King et al. 2011) The seed-borne nature of CPMMV has not been confirmed because various studies that have been carried out give different results. Seed-borne transmission of CPMMV on soybean, yard long beans, and green beans was reported by Brito et al. (2012). Examination of the transmission ability of CPMMV seeds in Clark variety soybeans by Tavassoli et al. (2009) in Iran showed that CPMMV was not seed transmitted. The study of the potential transmission of CPMMV seeds has not been carried out comprehensively in Indonesia, despite the important value of soybean for many peoples.

Nurrohman et al. (2019) found that the soybean resistance to CPMMV was more affected by the genotype of soybean than the dose of nitrogen as the essential nutrients of soybean. The use of resistance varieties and virus-free seed can reduce virus infection and disease development on field. Host plant and vector resistance are the most effective control measures against seed transmitted disease (Sastry 2013). The use of CPMMVinfected seeds has the potential to be a primary source of inoculum in the field. If CPMMV-infected seeds were planted, disease primary inoculum is available in the field since the initial phase of plant growth. In disease epidemiology, the number of initial inoculums plays an important role in disease development. It is assumed that with a high primary inoculum in the early phase of plant growth, it will cause a high rate of disease progression that triggers severe damage (Hull 2014). This research was 
conducted to determine the potential of seed transmission of CPMMV in 10 soybean varieties and evaluate the role of virus-infected seed as an initial inoculum in the field.

\section{MATERIALS AND METHODS}

\section{Infection Rate of CPMMV on Soybean Seed}

Five black soybean varieties ('Detam 1', 'Detam 2', 'Detam 3', 'Detam 4', and 'Malika'), and 5 yellow soybean varieties ('Anjasmoro', 'Dena-1', 'Argomulyo', 'Wilis', and 'Grobogan') were used in this experiment. The black and yellow soybeans seeds were obtained from Department of Agronomy and Horticulture, IPB University, in Bogor, West Java and Indonesian Legumes and Tubers Crop Research Institute, in Malang, East Java, respectively. Virus infection on seeds was determined by growing on test method. All seeds, 100 seeds for each variety, were grown in the screenhouse using seedling trays containing soil and rice husk $(2: 1 \mathrm{v} / \mathrm{v})$ as the growing media. The first leaves were collected seven days after planting (7 dap) and brought to the laboratory for virus detection using dot immunobinding assay (DIBA) method.

\section{Detection of CPMMV using Dot Immunobinding Assays (DIBA)}

Detection of CPMMV was conducted following DIBA method with modification (Sutrawati et al. 2017). Leaf samples were macerated in tris buffer saline (TBS: Tris$\mathrm{HCl} 0.02 \mathrm{M}$ and $\mathrm{NaCl} 0.15 \mathrm{M}, \mathrm{pH} 7.5$ ), i.e. $1 \mathrm{~g}$ leaf in $10 \mathrm{ml}$ TBS. Leaf extract was then spotted into nitrocellulose membrane (Hybond ${ }^{T M}-P$, Amersham Biosciences UK) as much as $2 \mu \mathrm{L}$ and the membrane was air dried. The membrane was then soaked in blocking buffer $(2 \%$ non fat milk in TBS) containing 2\% Triton X-100 and incubated at room temperature with gentle shaking ( $50 \mathrm{rpm}$ for 2 hours). The membrane was washed 5 times using $\mathrm{dH}_{2} \mathrm{O}, 5 \mathrm{~min}$ each wash with a gentle $100 \mathrm{rpm}$ shaking. The membrane was soaked in 1:3000 antibody solution (IgG-alkaline phosphatase CPMMV antibody in TBS containing $2 \%$ of non fat milk) and incubated at $4{ }^{\circ} \mathrm{C}$ overnight. The next day, the membrane was washed 5 times with TBS containing $0.05 \%$ Tween, then it was rinsed with $\mathrm{H}_{2} \mathrm{O}$. Finally, the membrane was soaked for 10 to $30 \mathrm{~min}$ in 10 $\mathrm{mL}$ substrate buffer (Tris- $\mathrm{HCl} 0.1 \mathrm{M}, \mathrm{NaCl} 0.1 \mathrm{M}$ and
$\mathrm{MgCl}_{2} 5 \mathrm{mM}$ ) containing $35 \mu \mathrm{l}$ nitro blue tetrazolium (NBT) and $45 \mu \mathrm{l}$ bromo chloro indolil phosphate (BCIP).

\section{Seed-transmission of CPMMV on Soybean var. Anjasmoro}

Soybean seeds var. Anjasmoro were collected from soybean growing regions in West Java, i.e. Bogor, Cianjur, and Cirebon in September to November 2015. All seeds were first examined for CPMMV infection rate as described earlier. Seeds from the same sources were used for field experiment, conducted at IPB university field station at Cikabayan, Dramaga in January to April 2016.

Field experiment was arranged in a completely randomized design with seed sources as the treatment, i.e. seeds var. Anjasmoro from Bogor, Cianjur, and Cirebon; each treatment was replicated 3 times. Soybean seeds was planted in $25 \times 25 \mathrm{~cm}$ planting space, with 2 seeds in each planting hole. Leave samples were collected for virus confirmation using DIBA as described earlier.

\section{RESULTS AND DISCUSSION}

\section{CPMMV Infection Rate on Soybean Seeds}

In general, germination rate of the seeds was quite high, which ranged from 59 to $89 \%$, except var. Denal (Table 1). The appearance of seeds of all varieties was normal, did not indicate any viral infection. Likewise, the seedlings looked healthy with no obvious viral symptom (Figure 2). However, CPMMV infection was detected based on virus detection using DIBA method. Three out of 5 varieties of black soybean, i.e. 'Malika', 'Detam 2', and 'Detam 3' were infected by CPMMV showed incidence rate of $27.7 \%$, $48.8 \%$, and $86.4 \%$, respectively. Two out of 5 varieties of yellow soybean, i.e. 'Argomulyo', and 'Anjasmoro' were infected by CPMMV with incidence rate of $44.4 \%$, and $57.3 \%$, respectively (Table 1). Two varieties of black soybean ('Detam 1' and 'Detam 4'), and 3 varieties of yellow soybean ('Wilis', 'Grobogan', and 'Dena 1') were not infected by CPMMV. Transmission of viruses through seed can be important for virus perpetuation, overwintering and long range dissemination. Seed transmission provides an initial source of inoculum for vector transmission of the virus that may have a considerable impact on crop yield.
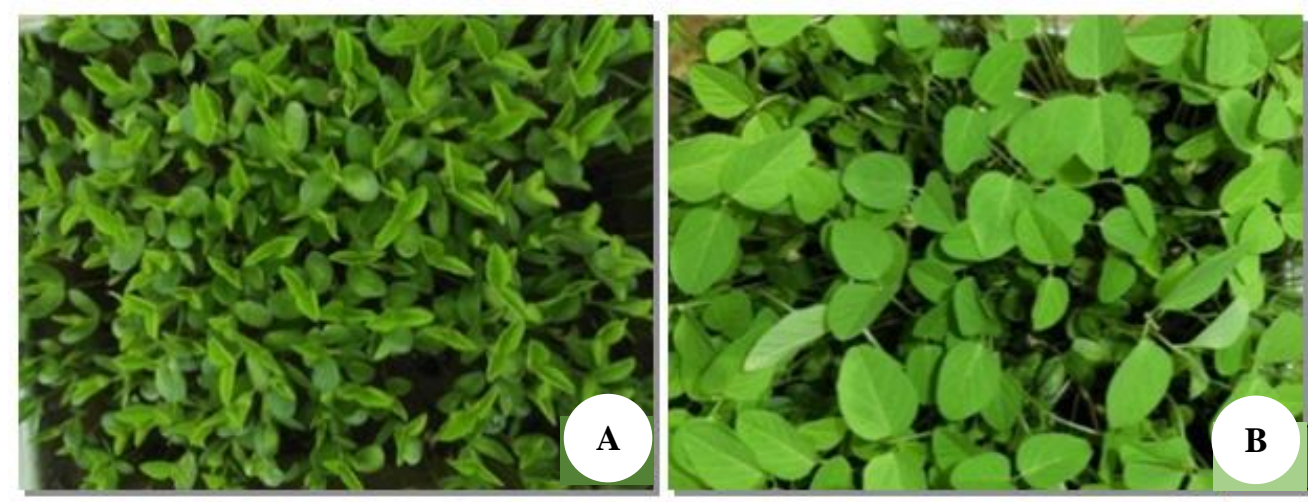

Figure 2. Soybean seedlings in the screenhouse, 4 days (A) and 7 days (B) after sowing 
Table 1. Detection of CPMMV on seedlings of soybean using dot immunobinding assay (DIBA)

\begin{tabular}{lcccc}
\hline \multicolumn{1}{c}{ Variety } & $\begin{array}{c}\text { No. } \\
\text { seedlings }\end{array}$ & \multicolumn{2}{c}{$\begin{array}{c}\text { DIBA reaction } \\
\text { Positive Negative }\end{array}$} & $\begin{array}{c}\text { Incidence of } \\
\text { CPMMV (\%) }\end{array}$ \\
\hline Black soybean & & & & \\
'Detam 1' & 78 & 0 & 78 & 0.0 \\
'Detam 2' & 84 & 41 & 43 & 48.8 \\
'Detam 3' & 59 & 51 & 8 & 86.4 \\
'Detam 4' & 79 & 0 & 79 & 0.0 \\
'Malika' & 83 & 23 & 60 & 27.7 \\
Yellow soybean & & & & \\
'Anjasmoro' & 89 & 51 & 38 & 57.3 \\
'Wilis' & 86 & 0 & 86 & 0.0 \\
'Argomulyo' & 81 & 36 & 45 & 44.4 \\
'Grobogan' & 88 & 0 & 88 & 0.0 \\
'Dena1' & 34 & 0 & 34 & 0.0 \\
\hline Note: ${ }^{*}$ Incidence of CPMMV was calculated as & no. positive \\
reaction on DIBA/total samples x 100\% &
\end{tabular}

Our detection indicated that CPMMV infection does not show visual symptoms on seeds and seedlings. Most seeds carrying viral infection appear normal. Therefore, physical seeds examination alone is not enough to be used as the basis for determining the status of seed health. However, there are several cases of virus infection that cause seed deformation and mottling. Infection of Pea seed-borne mosaic virus (PSbMV) and Pea enation mosaic virus (PEMV) on pea (Pisum sativum) causes shrivelled seed and sometimes seed mottling (Timmerman-Vaughan et al. 2009). Soybean mosaic virus caused seed mottling and severe yield losses on soybean (Kun et al. 2010). SMV infection often induce mottling of soybean seed coats in a host and virus strain-spesific manner (Domier et al. 2011). Research by Koning et al. (2003) on SMV indicated that SMV was accumulated in seedcoat. Mottling symptoms on soybean seed could be differentiated into 4 categories, i.e. none (no visual mottle), blemish (5 to $10 \%$ seedcoat is pigmented), band ( 25 to $30 \%$ seedcoat is pigmented, typically with 1 solid band encircling the seed), severe ( $\geq 70 \%$ seedcoat is pigmented). By ELISA, SMV was found in seedcoat samples, collected from both mottled and nonmottled seeds from SMV-infected plants. However, mottled seedcoats accumulated more SMV than nonmottled seedcoats. Research by Ellis et al. (2019), qualitative real time PCR and endpoint PCR assay results showed evidence of TMV infection in the endosperm and embryo, as well as in the developing seedling roots and cotyledon within 10 days of initiating seed germination. Therefore, in this paper the rate of seed transmission of CPMMV was determined by virus detection from soybean leaf 7 days after planting. In order to avoid false negative due to low rate of seed transmission, we conducted the detection using bulk samples. Further virus detection should be conducted, especially when planting virus-free seeds is recommended as disease control strategy.

Based on DIBA, CPMMV was detected from several soybean varieties. This is an important confirmation since previous research showed that CPMMV was not detected on seeds of soybean and peanuts in Indonesia (Horn et al.
1991). Similarly, examination of seed-transmitted ability of CPMMV on soybean var. Clark by Tavassoli et al. (2008) in Iran showed that CPMMV was not seed transmitted. The occurrence of seed transmission depends on several factors, namely virus species and strain, host species and cultivar, time of mother plant infection and environmental condition). Host species and cultivar have an effect on seed transmission. The virus might be seed transmitted on certain host species or cultivar but not on others. Researches have been done to understand the phenomenon in which some viruses are seed transmitted while the others are not. There are two ways in which virus can infect the embryo, i.e., by indirect invasion, for example through infection of the gametes before fertilization, or by direct embryo invasion after fertilization. Virus survival during seed transmission requires the immunity to host ploidy changes and its movement through vegetative and reproductive tissue. The virus must also be stable during seed maturation and storage period. Finally, the transmission will be successful when the virus is active during seed germination.

\section{Transmission efficiency of CPMMV on Seeds of Soybean var. Anjasmoro}

As examined earlier, CPMMV was detected from soybean seed var. Anjasmoro with quite high incidence. This is actually not a good situation since 'Anjasmoro' is the most common variety grown by farmers, especially in West Java. 'Anjasmoro' is preferable due to its seed size, which is big that suitable for food industry, especially for tofu and tempe.

In general, farmers in Cianjur and Bogor obtain seed sources from their own crops, while farmer in Cirebon obtain seed from UPTD Balai Benih Palawija, Plumbon (Cirebon). Seed quality of 'Anjasmoro' from farmers in Cianjur, Bogor, and Cirebon was quite good with normal physical appearance and high germination rate. However, seeds germination rate at field experiment were relatively lower than those at screenhouse, i.e. $70.4 \%$ to $85.8 \%$ and $81.3 \%$ to $98.3 \%$, respectively (Table 2 ). The difference in germination is thought to be related to differences in environmental conditions between field experiment and screenhouse.

Table 2. Seed germination rate and incidence of CPMMV on soybean var. Anjasmoro in the screenhouse and field experiment

\begin{tabular}{lcc}
\hline Seed source & $\begin{array}{c}\text { Germination rate } \\
(\boldsymbol{\%})\end{array}$ & $\begin{array}{c}\text { Incidence of } \\
\text { CPMMV }(\boldsymbol{\%})^{\mathbf{1}}\end{array}$ \\
\hline Screenhouse experiment $^{\mathbf{2}}$ & & \\
Cianjur & 90.3 & 45.0 \\
Bogor & 81.3 & 75.0 \\
Cirebon & 98.3 & 32.9 \\
Field experiment $^{\mathbf{3}}$ & & \\
Cianjur & 85.8 & 67.1 \\
Bogor & 75.3 & 81.3 \\
Cirebon & 70.4 & 57.9 \\
\hline
\end{tabular}

Note: ${ }^{1}$ CPMMV was detected by DIBA; \% incidence was calculated as no. positive reaction on DIBA/total samples $\mathrm{x} 100 \%$. ${ }^{2,3}$ Virus detection was conducted on 7 days after sowing and 6 weeks after planting for screenhouse and field experiment, respectively. 
Detection of CPMMV from seedlings in the screenhouse indicated that infection rate varied among seed sources, with the highest infection rate found on seeds from Bogor (75\%) followed by seeds from Cianjur $(45 \%)$ and Cirebon (32.9\%). Similarly, higher incidence of CPMMV was observed from field samples with the highest infection rate found on seeds from Bogor (81.3\%) followed by seeds from Cianjur $(67.1 \%)$ and Cirebon $(57.9 \%$ ) (Table 2). Infection rates in the field was higher than those in the screen house caused CPMMV infection in plants in the field can come from seeds and from vectors in the field from infected plant to healthy plants. Although CPMMV was positively detected from both screenhouse and field experiment, symptoms of CPMMV was only obvious on the field. None of seedlings in the screenhouse showed virus infection till 7 days after planting; while mottle symptoms on young leaves was appeared since the second week soybeans seeds were planted. CPMMV infection causes blotchy yellow leaf, mosaic or rough mosaic, wrinkled, chlorosis, and malformation of leaves depending on the age of soybean. Mottle symptoms on soybean was obvious at 14 days after planting. It is probably due to interaction between virus concentration on plants and the suitable environment, especially intensity of sunshine.

Cowpea mild mottle virus was found to be seedtransmitted, the symptoms on leaves of soybean were observed at 40-50 DAS (Yadav et. al 2013). Viruses that are capable of infecting seed embryos can be transmitted to the next generation. When outside embryo, for example in endosperm and testa, the virus is inactive. It was shown in PSbMV infection, in which more than $50 \%$ of mature pea seeds infected with PSbMV in the seedcoat, but only 2 to $3 \%$ of these seeds transmitted the virus. Therefore, detection method to determine the potency of seeds as transmission agent of the virus is crucial. Using serology and nucleic acid-based methods, inactive viruses might be detected and causes over estimation of seed transmission rate.

CPMMV was found in uncultivated plants belonging to several families, including Fabaceae (Macroptilum spp., Senna spp., Desmodium glabrum, Rhynchosia minima), Nyctaginaceae (Mirabilis jalapa), Cleomaceae (Cleome affinis), and Asteraceae (Blainvillea rhomboidea) (Lamas et al. 2017).

Identification of initial inoculum is one of the early prevention to subdue the epidemy of plant disaese. Virus detection techniques are important during the early developmental stages of a plant for the rapid detection for disease control strategies (Kumar et al. 2011). Seed-transmitted pathogens are very important in the disease epidemiology because the seeds play a role as the starting point for disease infection. Based on this research, infected soybean seed was proved to be initial inoculum resource of CPMMV. The high rate transmission of CPMMV on some soybean cultivar could initiate a disease epidemic in a new growing area.

\section{ACKNOWLEDGEMENTS}

The author would like to thank the Directorate of Research and Community Service of the Ministry of
Research, Technology and Higher Education for the funding of the Doctoral Dissertation Research 2016 Batch I, no: 044/SP2H/LT/DRPM/II/2016, 17 February 2016.

\section{REFERENCES}

Andayanie WR. 2012. Diagnosis penyakit mosaik (Soybean mosaic virus) terbawa benih kedelai. Jurnal Hama dan Penyakit Tumbuhan Tropika. 12 (2): 185-191. DOI: 10.23960/j.hptt.212185-191. [Indonesian]

Brito M, Fernandez-Rodriguez T, Garrido MJ, Mejias A, Romano M, Marys E. 2012. First report of Cowpea mild mottle Carlavirus on yardlong bean (Vigna unguiculata subsp. sesquipedalis) in Venezuela. Viruses 4 (12): 3804-3811. DOI: 10.3390/v4123804

Chang CA, Chien LY, Tsai CF, Lin YY, Cheng YH. 2013. First report of Cowpea mild mottle virus in cowpea and french bean in Taiwan. Plant Dis 97 (7): 1001. DOI: 10.1094/PDIS-10-12-0935-PDN

Domier LL, Hobbs HA, McCoppin NK, Bowen CR, Steinlage TA, Chang S, Wang Y, Hartman GL. 2011. Multiple loci condition seed transmission of Soybean mosaic virus (SMV) and SMV-induced seed coat mottling in soybean. Phytopathol 101: 750-756. DOI: 10.1094/PHYTO-09-10-0239

Ellis MD, Hoak JM, Ellis BW, Brown JA, Sit TL, Wilkinson CA, Reed TD, Welbaum GE. 2020. Quantitative real-time PCR analysis of individual flue-cured tobacco seeds and seedlings reveals seed transmission of Tobacco mosaic virus. Phytopathol 110: 194-205. DOI: 10.1094/PHYTO-06-19-0201-FI

Horn NM, Saleh N, Baliadi Y. 1991. Cowpea mild mottle virus could not be detected by ELISA in soybean and groundnut seeds in Indonesia. Neth J Plant Pathol 97 (2): 125-127.

Hull R. 2014. Plant Virology. Academic Press, London (UK).

King AM, Lefkowitz E, Adams MJ, Carstens EB. 2011. Virus Taxonomy: Ninth Report of the International Committee on Taxonomy of Viruses. Elsevier, Amsterdam.

Koning G, TeKrony DM, Ghabrial SA. 2003. Soybean seedcoat mottling: Association with Soybean mosaic virus and Phomopsis spp. seed infection. Plant Dis 87: 413-417. DOI: 10.1094/PDIS.2003.87.4.413

Kumar S, Udaya Shankar AC, Nayaka SC, Lund OS, Prakash HS. 2011. Detection of Tobacco mosaic virus and Tomato mosaic virus in pepper and tomato by multiplex RT-PCR. Lett Appl Microbiol 53: 359-363. DOI: 10.1111/j.1472-765X.2011.03117.x

Kun W, Wen-fu L, Lei Z, Chun-yan L, Xiao-shuang Z, Qing-shan C, Guohua H. 2010. Genetic analysis and molecular mapping of two SMV-resistance traits in soybean: Adult-plant resistance and resistance to seed coat mottling. Agric Sci China 9 (1): 11-18. DOI: 10.1016/S1671-2927(09)60062-6

Lamas NS, Matus VORL, Alves-Freitas DMT, Melo FL, Costa AF, Farra JC, Riberio SG. 2017. Occurrence of Cowpea mild mottle virus in common bean and associated weeds in Northeastern Brazil. Plant Dis 101 (10): 1828. DOI: 10.1094/PDIS-04-17-0562-PDN

Rahim YF, Damayanti TA, Ghulamahdi M. 2015. Deteksi virus yang menginfeksi kedelai di Jawa. Jurnal Fitopatologi Indonesia 11 (2): 68. DOI: 10.14692/jfi.11.2.68 [Indonesian]

Sastry KS. 2013. Seed-borne Plant Virus Diseases. Springer, India.

Sutrawati M, Hidayat SH, Soekarno BPW, Nurmansyah A, Suastika G. 2017. Host range of Cowpea mild mottle virus and esponse of soybean varieties. Jurnal Fitopatologi Indonesia 13 (6): 229-237. DOI: 10.14692/jfi.13.6.229

Tavassoli M, Shahraeen N, Ghorbani S. 2009. Serological and RT-PCR detection of Cowpea mild mottle carlavirus infecting soybean. J Genet Mol Virol 1 (1): 007-011.

Tavassoli M, Shahraeen N, Ghorbani S. 2008. Detection and some properties of cowpea mild mottle virus isolated from soybean in Iran. Pak J Biol Sci 11 (23): 2624-2628. DOI: 10.3923/pjbs.2008.2624.2628

Timmerman-Vaughan G, Larsen R, Murray S, McPhee K, Coyne C. 2009. Analysis of the accumulation of Pea enation mosaic virus genomes in seed tissues and lack of evidence for seed transmission in pea (Pisum sativum). Phytopathol 99: 1281-1288. DOI: 10.1094/PHYTO-99-111281

Yadav MK, Biswas KK, Lal SK, Baranwal VK, Jain RK. 2013. A distinct strain of cowpea mild mottle virus infecting soybean in India. J Phytopathol 161 (10): 739-744. DOI: 10.1094/PHYTO-99-11-1281 